\title{
Carbon Sequestration of Soil and Plants along IH-35 in Bexar County, Texas
}

\author{
Lauren Rangel ${ }^{1}$, Vikram Kapoor ${ }^{2,}$, Jeffrey Hutchinson ${ }^{1}$, and Samer Dessouky ${ }^{2}$ \\ ${ }^{1}$ Department of Environmental Science and Ecology, University of Texas at San Antonio, San Antonio, TX 78249 \\ ${ }^{2}$ Department of Civil and Environmental Engineering, University of Texas at San Antonio, San Antonio, TX 78249
}

\begin{abstract}
Soil and vegetation were evaluated along IH-35 within Bexar County for carbon content. The objectives of this study were to evaluate the vegetative composition and carbon sequestration potential of vegetation along IH-35. Three $20 \mathrm{~m}$ transects were placed at each site and percent vegetative cover was estimated and above ground plant biomass and soil was collected from three $0.25 \mathrm{~m}^{2}$ subplots along each transect. Plant and soil samples were analyzed for carbon content using the loss-on-ignition method. Two non-native grasses, bermudagrass and King Ranch bluestem, were the dominant cover. Bermudagrass was more efficient in absorbing $\mathrm{CO}_{2}$ compared to King Ranch bluestem. The top $10 \mathrm{~cm}$ of soil in all samples contained more organic carbon than the lower $10 \mathrm{~cm}$. Collection of field data has been completed and the soil and plant carbon content is being analyzed with the final results presented at the conference.
\end{abstract}

\section{Introduction}

Roadway corridors are anthropogenic ecosystems that are typically seeded or sodded with fast-growing, rhizomatous non-native grasses. In semi-arid regions such as Texas, low precipitation further limits plant growth and many species enter dormancy during periods of low precipitation. The United States Federal Highway Administration (FHWA) estimates that grasses make up $44 \%$ or 900,000 ha of the right-of-ways [1]. Texas is estimated to have ca. $22,370 \mathrm{~km}$ of roadways in the National Highway System [2] along with thousands more kilometers of local and state-maintained roadways.

There is a growing interest in the potential for roadside vegetation and soils to capture and store carbon. Emissions of $\mathrm{CO}_{2}$ generated from combustion of fossil fuel comprises roughly 80 percent of the anthropogenic greenhouse gases contributing to global climate change. There are greater than $482,800 \mathrm{~km}$ of roadways and 23.8 million registered motor vehicles in Texas, and $5494 \mathrm{~km}$ of highway and 1.5 million registered vehicles in Bexar County [3]. Transportation accounts for 34\% of total $\mathrm{CO}_{2}$ emissions [4]. Carbon sequestration is one method of reducing carbon dioxide levels in the atmosphere, and it can be accomplished biotically by vegetation and soil. A Florida Department of Transportation study valued carbon capture and storage at \$157-363 million along highways using a conservative price for carbon [5]. Other studies reported that high vegetation species and diversity in grasslands resulted in greater carbon sequestration than low diversity grasslands [6,7].

Plants absorb $\mathrm{CO}_{2}$ along roadways which is used in photosynthesis and the carbon molecule is synthesized into multiple compounds. These compounds are stored in above and below ground biomass. Carbon from senescent plants and their parts is returned to the atmosphere through decomposition or incorporated into the soil profile by microorganisms. In addition to carbon sequestration, roadside vegetation provides other benefits such as reducing air and noise pollution, slowing down and trapping sediment, and uptake of nutrients and metals. Limited information is known about the carbon pools associated with soils and plant species along IH-35 in San Antonio, Texas. The objectives of this study were to evaluate the vegetation composition and carbon sequestration potential of soils and plant species within the IH-35 corridor bisecting Bexar County, Texas.

\section{Methods}

\subsection{Field evaluation}

Six sites were surveyed along I-35 in Bexar County (Fig. 1). Three $20 \mathrm{~m}$ line transects were established at each site, and percent vegetative cover by species was estimated along each line. Three $0.25 \mathrm{~m}^{2}$ plots were randomly placed along each transect and all above ground biomass, including leaf litter, was clipped and bagged by species. Two $20 \mathrm{~cm}$ soil cores were extracted with a hand-held auger from each plot and separated as the top portion $(0-10 \mathrm{~cm})$ and lower portion $(10.1-20$ $\mathrm{cm})$.

\footnotetext{
* Corresponding author: vikram.kapoor@utsa.edu
} 


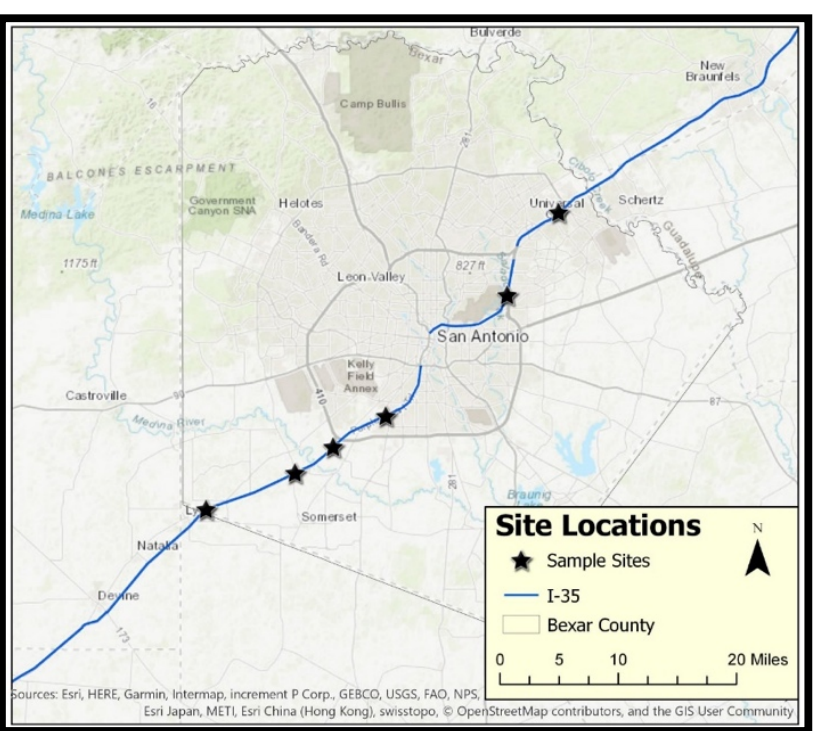

Fig. 1. Study sites $(n=6)$ extended northeast to southwest along IH-35 in Bexar County.

\subsection{Laboratory evaluation}

Carbon content of soil, plants, and leaf litter was estimated with the loss-on-ignition method [8]. Plant samples were air dried for 24 hours, and then oven dried at $115^{\circ} \mathrm{C}$ for 72 hours and weighed. Soil samples were air dried for 48 hours, sieved to $2.0 \mathrm{~mm}$, and then oven dried at $115^{\circ} \mathrm{C}$ for 48 hours. After oven drying, soil samples were weighed to the nearest $0.001 \mathrm{~g}$ and placed into a muffle furnace at $360^{\circ} \mathrm{C}$ for 4 hours, the samples were then weighed to the nearest $0.001 \mathrm{~g}$. Soil and plant carbon content was determined using the following equations [9]:

Soil carbon content $=$ soil dry weight $/ 1.724$

Plant carbon content $=$ plant dry weight $\times 0.475$

Photosynthesis measurements were taken on the dominant grasses in each transect with a portable infrared gas analyzer (LI-6400 Portable Photosynthesis System). The light curves were created using a $400 \mu \mathrm{mol}$ gas flow rate and photosynthetically active radiation (PAR) levels of $0,5,10,25,50,100,200,400,600,800$, $1000,1200,1600$, and $2000 \mu \mathrm{mol} / \mathrm{m}^{2} / \mathrm{s}$. Photosynthesis response curves were developed from the mean of four measurements per plant to determine which plants are more efficient in absorbing $\mathrm{CO}_{2}$ under ambient conditions at varying light intensities. Means and standard errors were calculated for quantum yield efficiency $(\mathrm{QY})$, maximum photosynthesis rate $\left(\mathrm{A}_{\max }\right)$, light saturation point $\left(\mathrm{L}_{\mathrm{sp}}\right)$, light compensation point $\left(\mathrm{L}_{\mathrm{cp}}\right)$, and dark respiration rate $\left(\mathrm{R}_{\mathrm{d}}\right)$.

Descriptive statistics were computed for all data. Differences $(\mathrm{p}<0.05)$ in the carbon content of plant species were tested with a one-way ANOVA to determine which species are sequestering more carbon. Differences $(\mathrm{P}<0.05)$ in the carbon content of the soil were compared among sites and dominant vegetation cover. If differences were detected with an ANOVA, a Tukey's mean separation test was used to determine differences among plant species and sites. Data were transformed if needed to meet homogeneity of variance assumptions.

\section{Results and discussion}

The data collected during May to August 2018 has only been partially analyzed. Preliminary results indicate that grassy stripes along $\mathrm{IH}-35$ in Bexar County are dominated by King Ranch bluestem (Bothriochloa ischaemum var. songarica) and bermudagrass (Cynadon dactylon), two non-native grasses (Fig. 2). A total of 55 species were observed among the six sites indicating low species richness. Diversity indices have not been evaluated, but are likely to be low as 5 of the 6 sites were dominated by 1 or 2 non-native species. Native plant coverage was low at all sites. Two native species, common ragweed and Texas frog-fruit, comprised 33.3 and $13.6 \%$ coverage, respectively at single sites but most native species coverage was less than $10 \%$. Out of the nine dominant plant species among the study sites, six are native and three are non-native. The three non-native species include bermudagrass, Johnsongrass (Sorghum halepense), and King Ranch bluestem, all of which are invasive in Texas and form monocultures.

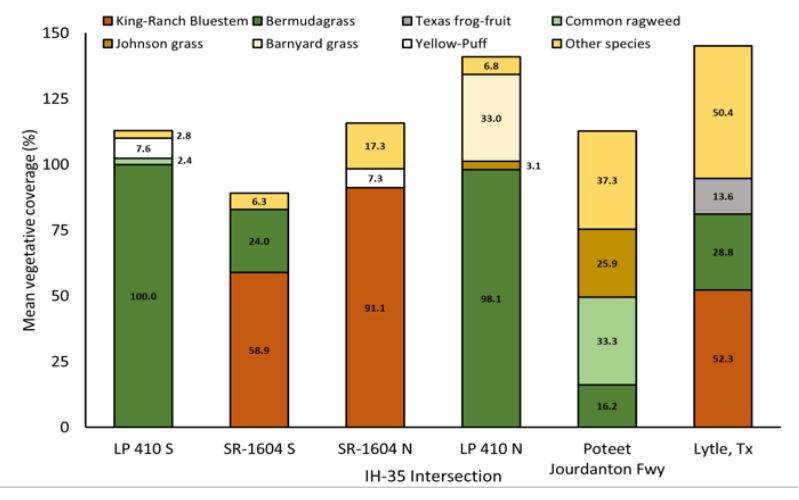

Fig. 2. Percent vegetation cover by species at the six sites sampled.

Only $50 \%$ of the soil and $0 \%$ of the plant samples have been analyzed for carbon content. Soil carbon content was greater in the top $10 \mathrm{~cm}$ compared to soil carbon at 10-20 cm below the surface based on limited samples (Fig. 3). Carbon was highest in association with common ragweed (Ambrosia artemisiifolia), a native species, and lowest in association barnyard grass (Echinocloa crus-galli), a non-native species. Bermudagrass and King Ranch bluestem were intermediate in carbon content. Analysis of the carbon content in other species will provide more insight into the ability of native species to sequester carbon and translocate it into roots compared to non-native species.

Soils located in arid regions have low concentrations of carbon due to infrequent precipitation and decreased microbial activity [10]. In New Mexico, soil carbon was strongly correlated with precipitation [11]. The results of this study may represent minimal estimates of carbon due to minimal precipitation during the summer sampling period. Pulses of carbon sequestration may 
occur during precipitation events. Other factors that may limit carbon sequestration along IH-35 include soil compaction and low organic matter. An assessment of soil and plant carbon content is affected by environmental variability that includes precipitation and temperature, and different soil types. In semi-arid regions such as Texas, carbon sequestration is likely a pulsed event dependent on precipitation and vegetation diversity. Increased plant species richness and diversity along roadways may result in greater annual carbon sequestration. As $\mathrm{CO}_{2}$ levels increase, it is unclear if $\mathrm{C}_{3}$ plants will become more productive than $\mathrm{C}_{4}$ plants [12]. Roadsides with a mixed diversity of $\mathrm{C}_{3}, \mathrm{C}_{4}$, cool and warm season species would be more efficient at carbon sequestration on a year-round basis.

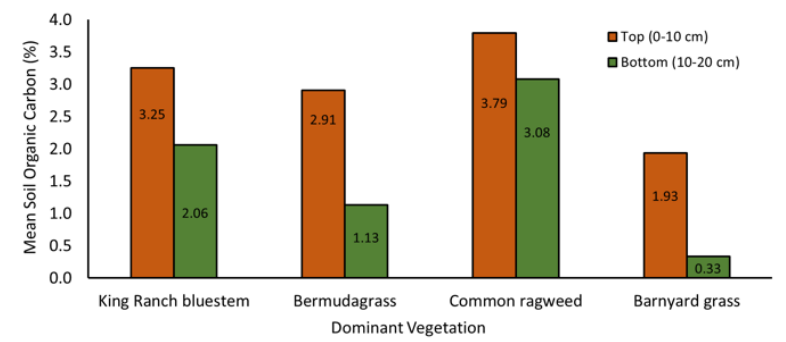

Fig. 3. Mean percent soil organic carbon by dominant vegetative cover (by mass) within each plot.

Warm season grasses generally have a higher root to shoot ratio comprised of greater fine root densities than cool season grasses [13, 14] and the continual senescence of fine roots incorporates greater carbon into soil profile [15]. Bermudagrass and King Ranch bluestem are warm season grasses that go dormant for 34 months in South-Central Texas, limiting soil carbon sequestration in the winter. Bermudagrass is a stoloniferous and rhizomatous species which translocate more carbon into multiple roots along nodes. King Ranch bluestem is a clump grass with shallow roots, spreads by short stolons, and occurs in high densities. Conversely, cool season grasses and forbs are important along roadways carbon sequestration, trapping sediment and preventing erosion during the cooler months in South-Central Texas.

In this study, bermudagrass was more efficient in $\mathrm{CO}_{2}$ assimilation at higher light compared to King Ranch bluestem (Fig. 4). Quantum efficiency (QY), $\mathrm{CO}_{2}$ saturated assimilation $\left(\mathrm{A}_{\max }\right)$, light compensation $\left(\mathrm{L}_{\mathrm{cp}}\right)$, and light saturation $\left(\mathrm{L}_{\mathrm{cp}}\right)$ rates were greater for bermudagrass compared to King Ranch bluestem (Table 1). Based on the respiration rate, bermudagrass experiences minimal photorespiration and has a greater tolerance to higher irradiances and temperatures than King Ranch bluestem. Several warm season native grasses occurred in the study sites but coverage was less than $5 \%$. These native species included little bluestem (Schizachyrium scoparium), side oats gamma (Bouteloua curtipendula), buffalograss (Buchloe dactyloides), silver bluestem (Bothriochloa laguroides), white tridens (Tridens albescens), and purple threeawn (Artistida purpurea). Comparisons of native to non-native grasses will provide insight on native species capable of competing with non-native grasses. In disturbed and compacted roadside soils, carbon may be a limiting factor in native plants becoming established. Carbon soil content in an undisturbed Central Texas prairie containing a mix of native and nonnative species was greater than improved grasslands and agricultural sites [16]. In disturbed and compacted roadside soils, carbon may be a limiting factor in native plants becoming established. In highly disturbed soils along roadways, it may take decades for the soil carbon content to increase its carbon storage capacity. Consequently, many roadside corridors may be well below their capacity to store carbon.

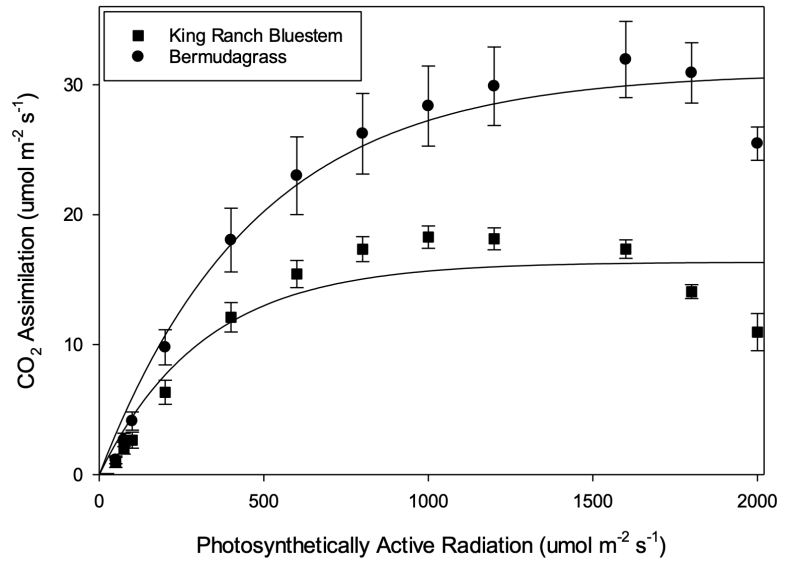

Fig. 4. Modeled light response curve (black lines) for $\mathrm{CO}_{2}$ assimilation to increasing light levels for King Ranch bluestem $(n=4)$ and bermudagrass $(n=4)$. Symbols represent mean recorded values and bars represent standard error.

Table 1. The mean (standard error) maximum net photosynthetic rates quantum yield efficiency $(Q Y ; \mu \mathrm{mol} \mathrm{CO} 2$ $\left.\mathrm{m}^{-2} \mathrm{~s}^{-1} / \mu \mathrm{mol} \mathrm{m} \mathrm{m}^{-2} \mathrm{~s}^{-1}\right),\left(\right.$ Amax; $\left.\mu \mathrm{mol} \mathrm{CO} \mathrm{Cm}^{-2} \mathrm{~s}^{-1}\right)$, light compensation point $\left(\mathrm{L}_{\mathrm{cp}} ; \mu \mathrm{mol} \mathrm{m} \mathrm{m}^{-2} \mathrm{~s}^{-1}\right)$, light saturation point

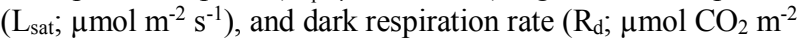
$\mathrm{s}^{-1}$ ) for bermudagrass and King Ranch bluestem.

\begin{tabular}{ccc}
\hline Parameter & $\begin{array}{c}\text { Bermud- } \\
\text { agrass }\end{array}$ & $\begin{array}{c}\text { King Ranch } \\
\text { bluestem }\end{array}$ \\
\hline QY $\left(\mu \mathrm{mol} \mathrm{CO} \mathrm{CO}_{2}^{-2} \mathrm{~s}^{-1}\right) /(\mu \mathrm{mol}$ & $0.06(0.01)$ & $0.03(0.005)$ \\
$\left.\mathrm{m}^{-2} \mathrm{~s}^{-1}\right)$ & $33.2(1.9)$ & $16.9(1.1)$ \\
$\mathrm{A}_{\max }\left(\mu \mathrm{mol} \mathrm{CO} \mathrm{Cm}^{-2} \mathrm{~s}^{-1}\right)$ & $33.9(1.7)$ & $28.9(1.8)$ \\
$L_{c p}\left(\mu \mathrm{mol} \mathrm{CO} \mathrm{m}^{-2} \mathrm{~s}^{-1}\right)$ & $589(41.2)$ & $529(32.8)$ \\
$L_{\text {sat }}\left(\mu \mathrm{mol} \mathrm{CO} \mathrm{CO}_{2} \mathrm{~m}^{-1}\right)$ & $-0.98(0.25)$ & $-2.03(0.85)$ \\
$R_{d}\left(\mu \mathrm{mol} \mathrm{CO} \mathrm{CO}_{2} \mathrm{~m}^{-2} \mathrm{~s}^{-1}\right)$ & & \\
\hline
\end{tabular}

The results of the study are preliminary with only $25 \%$ of the data analyzed. In conclusion, two non-native grasses dominated the sites sampled along IH-35 in Bexar County, Texas. Soil carbon content was higher in the upper $10 \mathrm{~cm}$ of the soil profile compare to the lower $10-20 \mathrm{~cm}$ portion. Based on limited analysis, soil carbon content was higher under coverage of a native species (common ragweed) compared to three non-native species. Upon completion of final data analysis, the vegetative coverage will be used to create a GIS model of the different vegetation types along IH-35 to estimate carbon sequestered along IH-35. The estimated carbon content (t/ha) of each site will be calculated for all plant species, total plant and leaf litter, soil, and total (plant, leaf litter, and soil) to evaluate the carbon sequestration 
potential of roadside vegetation and soils. The findings of this research will be utilized to make recommendations on future plantings along roadways in Bexar County to maximize carbon sequestration and develop low impact development along roadways. Additional studies are needed on seasonal differences in carbon sequestration and photosynthesis rates among $\mathrm{C}_{3}$, $\mathrm{C}_{4}$, warm and cool season grasses, and soil associations in South-Central Texas.

\section{References}

1. USDOT-FHWA, United States Department of Transportation Federal Highway Administration (2010). U.S. Highways and Climate Change: Carbon Sequestration Pilot Program. U.S. Department of Transportation Federal Highway Administration. Available at: http://actrees.org/files/Research/fhwa_carbon_seque stration_pilot_program.pdf. Accessed: August 23, 2018.

2. S.D. Earsom, C. Poe, T. Perrone, R. Hallett, M. Greenfield. (2010). Carbon Sequestration Pilot Program: Estimated Land Available for Carbon Sequestration in the National Highway System. U.S. Department of Transportation, Federal Highway Administration, Office of Planning, Environment, and Realty, Final Report May 2010. Available at: https://www.fhwa. dot.gov/environment/sustainability/energy/publicati ons/carbon sequestration/index.cfm. Accessed: August 12, 2018.

3. E.C. Alvarez, ed. (2016). Texas Almanac 20162017. Texas Historical Association, Austin, TX.

4. Environmental Protection Agency (2017). Inventory of U.S. Greenhouse Gas Emissions and Sinks: 1990-2015. Available at: https://www.epa.gov/sites/production/files/201702/documents/2017_complete_report.pdf. Accessed: August 23, 2018.

5. G.L. Harrison, (2014). Economic impact of ecosystem services provided by ecologically sustainable roadside right of way vegetation management practices. Final report, Florida Department of Transportation, Contract No. BDK75-977-74, Tallahassee, FL.

6. S. Steinbeiss, H. Bebler, C. Engels, V. Temperton, N. Buchmann, R. Christiane, Y. Yvonne, J. Baade, M. Habekost, G. Gleixner (2008). Plant diversity positively affects short-term soil carbon storage in experimental grasslands. Global Change Biology 14:2937-2949.

7. K. Singh, G. Singh (2015). Roadside vegetation diversity of Jodhpur district and its role in carbon sequestration and climate change mitigation. Advances in Forestry Science 2:23-33.

8. W.E. Dean, Jr. (1974). Determination of carbonate and organic matter in calcarcous sediments sedimentary rocks by loss on ignition. Journal of Sedimentary Petrology 44:242-248.
9. D.W. Nelson, L.E. Sommers (1996). Total carbon, organic carbon, and organic matter. pp 961-1010 in A.L. Page (ed.) Methods of Soil Analysis. Part 2. Chemical and Microbiological Properties. 2nd Edition, Agronomy Series No. 9, ASA SSSA, Madison.

10. Lal, R. (2004). Soil carbon sequestration to mitigate climate change. Geoderma 123:1-22.

11. W.C. Dunn, (2013). Assessing the Potential to Sequester Carbon within State Highway Rights-ofway in New Mexico: Phase I: Inventory of Soil Organic Carbon and Current Management Practices. Report No. NM10ENV-01. New Mexico Department of Transportation Research Bureau, Albuquerque, NM. Available at: http://dot.state.nm.us/content/dam/nmdot/Research /NM10ENV_01_Carbon_Final\%20Report_032213. pdf. Accessed: $\overline{\text { August }}$ 23, 2018.

12. P.B. Reich, S.E. Hobbie, T.D. Lee, M.A. Pastore (2018). Unexpected reversal of $\mathrm{C}_{3}$ versus $\mathrm{C}_{4}$ grass response to elevated $\mathrm{CO}_{2}$ during a 20-year field experiment. Science 360:317-320.

13. J.D. Derner, G.E. Shuman (2007). Carbon sequestration and rangelands: a synthesis of land management and precipitation effects. Journal of Soil and Water Conservation 62:77-85.

14. J.D. Reeder, G.E. Schuman, J.A. Morgan, and D.R. LeCain (2004). Response of organic and inorganic carbon and nitrogen to long-term grazing of the shortgrass steppe. Environmental Management 33:485-495.

15. R.A. Gill, I.C. Burke, W.K. Lauenroth, D.G. Milchunas (2002). Longevity and turnover of roots in the shortgrass steppe: influence of diameter and depth. Plant Ecology 159:241-251.

16. K.N. Potter, H.A. Torbert, H.B. Johnson, C.R. Tischler (1999). Carbon storage after long-term grass establishment on degraded soils. Soil Science 164: 718-725. 